\title{
LITERATURE
}

DOI https://doi.org/10.30525/978-9934-26-180-0-6

\section{ФАНАТИЧНА ЛЮБОВ ДО ПРАВДИ: ШТРИХИ ДО ПСИХОПОРТРЕТУ ТЕОДОСІЯ ОСЬМАЧКИ}

\author{
Бойко В. В. \\ аспірантка кафедри украӥнської та зарубіжної літератури \\ Центральноукраӥнський державний педагогічний \\ університет імені В. К. Винниченка \\ м. Кропивницький, Украӥна
}

Нині назріла потреба переосмислення наукових надбань, що зумовлює перепрочитання класичної літератури. Особливої уваги заслуговує епоха 20-30-pp XX століття, оскільки саме для цього часу характерні найбільші потрясіння в українському культурному житті XX ст.: від яскравого самобутнього розквіту українського художнього слова до жорстокого знищення українських митців, яке роками були під грифом «секретно».

Українська література, до якої протягом довгого часу був закріплений статус селянської, особливо потребує дослідження харизматичних постатей, зокрема реконструкції їхніх психопотретів.

На основі спогадів сучасників про Тодося Осьмачку, серед яких «Живий Осьмачка : Спогади» (упорядник С. Козак), Ю. Стефаника «Моїм синам, моїм приятелям», В. Коваленко «Русалко 3 Куцівських ярів», М. Слабошпицький «Поет із пекла», зроблено спробу окреслити штрихи до психопортрета митця.

Тодосій Степанович Осьмачка - письменник незвичайної й трагічної долі. На сьогодні існує велика кількість всебічних наукових розвідок, присвячених життю і творчості митця. Грунтовно розглянуто різні аспекти біографії та творчості письменника в дослідженнях В. І. Біляїва «Спогади про Т. Осьмачку», М. Г. Жулинського «Тодось Осьмачка. Приречений на самотність і вигнання...», Н. В. Зборовської «Танцююча зірка Тодося Осьмачки», В. М. Коваленко «Русалко з Куцівських ярів», Ю. А. Лавріненка «Неподоланий поет», В. Ф. Покальчука «Тодось Осьмачка (фрагмент зі спогаду)», М. А. Скорського «Тодось Осьмачка. Життя і творчість», М. Ф. Слабошпицького «Поет із пекла», О. Д. Тарнавського «Три поети еміграції» Ю. В. Шереха «Над Україною дзвони гудуть» тощо. 
Варто також зазначити, про дисертацію на здобуття наукового ступеня кандидата філологічних наук О. Ю Піскун «Психоаналістична інтерпретація прози Т. Осьмачки», яку дослідниця здійснила на основі аналізу психобіографії письменника. Однак значення особистості Т. Осьмачки в українському літературознавстві досі залишається не до кінця осягненим.

Проаналізувавши теорії в галузі гуманістичного напрямку (представники - А. Маслоу, К. Р. Роджерс, Г. Олпорт та ін.) та егопсихології (представники - М. Еріксон, М. Фромм, К. Хорні та ін.) літературознавець С. П. Михида подає таку дефініцію поняття особистість митця - «це надзвичайно складне психофізіологічне утворення, створення повноформатного портрету якого вимагає з'ясування особливостей темпераменту, емоційного-вольової сфери, рис характеру [5, с. 19].

Тож ми зосереджуємось на свідомій стороні душі письменника та торкаємось однієї з найяскравіших рис характеру, про яку згадують у спогадах друзі, колеги, знайомі Т. Осьмачки. У дослідженні дотримуємось основного принципу реконструювання психопортрета «автора особистості - характеру - темпераменту» [5, с. 20], який полягає через мегатекст, тобто «джерельного дискурсу експлікації усіх буттєвих (біографія) та психофізіологіних (психобіографія) характеристик художника слова, які формують притаманні саме йому вияви художності $[5$, c. 20$]$.

У збережених спогадів про Тодося Осьмачку зустрічаємо особливу рису характеру митця, яку Ю. Стефаник називає «найбільш подивугідною прикметою» (підкреслення наше - В. Бойко) [2, с. 263], це «любов до npaвdu». Звертаємо увагу одразу на два спогади, у яких до виділеної риси характеру додається означення «фанатична». Це спогад М. Кейван, яка згадує: «Коли я вважаю Осьмачку великою індивідуальністю, то маю на думиі не тільки його величину в літературі. Не мени великим він був $i$ характером, патріотизмом, світосприйманням, а понад усе фанатичною любов'ю до правди» (підкреслення наше - В. Бойко) [1, с. 35] та Ю. Стефаника, який ще більше увиразнює фанатичну любов до правди як таку, «що межувала з одержимістю» [2, с. 263].

Можемо впевнено сказати, що ця риса характеру сформувалася в підсвідомості письменника давно, ще з дитинства. Цьому сприяли близькі стосунки митця зі своїм батьком, чию модель поведінки він перейняв. Як зазначає В. Коваленко, саме від батька передана «фанатична любов до чесності, правдивості» (підкреслення наше - В. Бойко) [3, с. 32].

На фоні життєвих перепетій, панування у свідомості народу червоного диктату, який винищував у зародку будь-які прояви правди, така риса 
характеру Тодося Осьмачки тільки набувала ваги, видозмінювалась у своїх проявах та проникала у всі сфери його життя.

Митець активно демонструє цю рису в різних виявах. Наприклад, фанатична любов до правди межувала з нетерпимістю до інших людей, у яких письменник помічав неправду. У щоденникових записах П. Тичини, які аналізує В. Біляїв, зафіксований випадок спілкування дружини П. Тичини Ліди з Т. Осьмачкою, під час якого останній звинував автора «Сонячних кларнет», у тому, що той крав його образи. На основі цієї ситуації В. Біляїв зазначає, що «ці записи Тичини кидають світло на двадцятисемилітнього тоді Осьмачку» [1, с. 99] і найперше в тому, що «Осьмачка осуджував роль поета як оспівувача будь-чого, щцо не відповідас правді〉 (підкреслення наше - В. Бойко) [1, с. 99]. Т. Осьмачка також був радикальним у своїх переконаннях та своїй творчості, залишаючись чесним перед собою та нацією у «своєму письменницькому обов'язку - писати правду" (підкреслення наше - В. Бойко) [7, с. 31].

Мегатекст дає можливість стверджувати, що особистість Тодося Осьмачки цілком вписується в концепцію К. Леонгарда про акцентуації характеру, тобто надзвичайне підсилення окремих його рис. Дослідник поєднує поняття «акцентована особистість» і «акцентуйовані риси» та дає визначення поняттю «актентуйовані особистості» як не хворим, а здоровим людям «зі своїми індивідуальними особливостями» [4].

Необхідність заглиблення у психологічну термінологію зумовлена можливістю таким чином краще дослідити психофізіологію письменника, а також спільність літературознавства та психології на рівні знань про людину, що сприяє віднайденню механізмів творчих інтенцій. Цю концепцію підтверджують слова В. Коваленко про те, що «розуміння невідворотної трагедії, пов'язаної із винищенням української нації, постійні переслідування поета за слово правди, життєва невлаштованість, тяжка фізична праця через безгрошів'я заради існування ... - це та інше «переплавляється» Осьмачкою в творчість із метою відчуття досконалої свободи бодай у слові» [3, с. 30].

За класифікацією К. Леонгарда ми можемо визначити тип акцентуації характеру Т. Осьмачки як застрягаючий (ригідний), виразними рисами якого є: правдолюбоство, підозрілість, вразливість, наполегливість у досягненні цілей, честолюбство тощо.

В межах цього дослідження ми розглянули одну з найяскравіших рис застрягаючого типу характеру особистості митця, яка підтверджена мемуаристами.

Отже, особистість митця $є$ надзвичайно складним психофізіологічним утворенням, створення психопортрету письменника це тонка, ювелірна 
робота, яка потребує копіткого огранення притаманних йому особливостей, які стануть важливим інструментом для подальшого осмислення його психоструктури та психосвіту. Проаналізований мегатекст дає можливість стверджувати, що особистість Тодося Осьмачки повністю вписується в концепцію К. Леонгарда про акцентуації характеру, оскільки найяскравішою рисою, яка виявляється у спогадах про митця, $є$ фанатична любов до правди.

\section{Література:}

1. Живий Осьмачка: спогади / упоряд. С. Козак. Детройт : «Українські вісті», 1998. 205 с.

2. Клиновий Ю. Моїм синам, моїм приятелям : статті й есеї. Едмонтон - Торонто : «Слово», 1981. 616 с.

3. Коваленко В. Русалко з Куцівських ярів. Черкаси : Видавець Ю. А. Чабаненко, 2018. 220 с.

4. Леонгард К. Акцентуйовані особистості. К., пер. 3 нім. [попер. сл. і ред. Блейхера В.М.]. 2-е вид. стер. Київ: «Вища школа», 1989. 375 с.

5. Михида С. П. Психопоетика українського модерну : Проблема реконструкції особистості письменника: монографія. Кіровоград : «Поліграф - Терція», 2012. 362 с.

6. Михида С. П. Модерн d'Ukraine: особистість - мегатекст поетика. Кіровоград : «Поліграф - Сервіс», 2013. 336 с.

7. Скорський М. Тодось Осьмачка: життя і творчість. Київ : Український Центр духовної культури, 1999. 224 с. 